\title{
Analysis of oral risk-factors for ventilator- associated pneumonia in critically ill patients
}

Ademar Takahama Jr ( $\nabla$ ademartir@uel.br)

Universidade Estadual de Londrina

\section{Vitoria laros de Sousa}

Londrina State University

\section{Elisa Emi Tanaka}

Londrina State University

\section{Evelise Ono}

Londrina State University

Fernanda Akemi Nakanishi Ito

Londrina State University

Priscila Paganini Costa

Londrina State University

Maria Beatriz Bergonse Pedrialli

Londrina State University

Heliton Gustavo de Lima

Londrina State University

\section{Marco Aurélio Fornazieri}

Londrina State University and Pontifical Catholic University of Paraná

\section{Leticia Sassaki Correia}

Londrina State University

Lucienne Tibery Queiroz Cardoso

Londrina State University

Claudia Maria Dantas de Maio Carrilho

Londrina State University

\section{Research Article}

Keywords: ventilator-associated pneumonia, risk-factor, oral health, coated tongue

Posted Date: May 11th, 2020

DOl: https://doi.org/10.21203/rs.3.rs-23662/v1 
License: (c) (i) This work is licensed under a Creative Commons Attribution 4.0 International License. Read Full License

Version of Record: A version of this preprint was published at Clinical Oral Investigations on June 27th, 2020. See the published version at https://doi.org/10.1007/s00784-020-03426-x. 


\section{Abstract}

Objective: This a cross-sectional study to evaluate the association between oral health findings and ventilator-associated pneumonia (VAP) among critically ill patients in intensive care units (ICU).

Material and Methods: Data were collected from medical records, and a detailed oral physical examination was performed on 663 critically ill patients on mechanical ventilation. Data were statistically analysed using univariate and logistic regression models relating the development of VAP with the oral findings.

Results: At oral physical examination, the most frequent findings were tooth loss (568 - 85.67\%), coated tongue (422 - 63.65\%) and oral bleeding (192 - 28.96\%). Patients with a coated tongue or oral bleeding on the first day of ICU hospitalization developed more VAP than did patients without these conditions ( $20.14 \%$ vs $13.69 \%$ : $p=0.02 ; 23.44 \%$ vs $15.50 \%$ : $p=0.01$, respectively). In the logistic regression, a coated tongue and oral bleeding were considered independent risk factors for VAP development [OR=1.60 (1.022.47) and $\mathrm{OR}=1.59$ (1.05 - 2.44), respectively].

Conclusions: The presence of a coated tongue and oral bleeding in ICU admission could be considered markers for the development of VAP.

Clinical relevance: The results of this paper reinforces the importance of proper maintenance of oral hygiene before intubation, which may lead to a decrease in the incidence of VAP in the ICU. This is particularly important in the COVID-19 current scenario, where more people are expected to need mechanical ventilation, consequently increasing cases of VAP.

\section{Introduction}

It is becoming increasingly accepted that the oral cavity can be the site of origin for the dissemination of pathogenic microorganisms to distant sites, mainly in immunocompromised patients.[1] One of these important infections is pneumonia, in which initiation and progression could be influenced by oral biofilm through the relocalization of oral bacteria into the lower respiratory tract.[2] Some studies have associated oral bacteria-associated conditions, such as periodontal disease and wearing dentures while sleeping, with a high risk of pneumonia and its complications.[3]

In patients under mechanical ventilation in ICUs, the endotracheal tube may act as a conductor of the microorganisms from the oral cavity to the lower airway, inducing the development of pneumonia.[4,5] This invasion of microorganisms to the lower respiratory tract may lead to the development VAP. VAP is defined as a pneumonia that occurs after two days (48 hours) of intubation and is the most common type of nosocomial pneumonia.[6, 7] VAP represents approximately $9 \%$ to $40 \%$ of all infections acquired by critically ill patients in ICUs. The diagnosis of VAP represents an important cause of morbidity and mortality, as well as of extended hospital stays and higher hospital costs.[8] 
Therefore, this study was conducted to evaluate the possible association between oral health and VAP among critically ill patients in the ICU.

\section{Methods}

\section{Patient selection}

This is a cross-sectional study conducted at the University Hospital of Londrina in Brazil between February 2016 and April 2019. All critically ill patients on mechanical ventilation (MV) admitted to the adult ICU were included in the study. Patients who could not tolerate oral hygiene, e.g., patients with intracranial hypertension, were excluded. All participants and their legal guardians received oral and written information prior to participation. The legal guardian of unconscious patients or those with a decreased level of consciousness signed a consent form on the patient's behalf. The study protocol was reviewed and approved by the local Human Research Ethics Committee. (CAAE 53864716.9.0000.523)

Clinicodemographic data, such as age, gender, reason for ICU admission, presence of comorbidities and VAP development, were obtained from medical records. The diagnosis of VAP was performed by the intensive care team. The simplified acute physiology score 3 (SAPS3), which consists of a severity scoring system to predict hospital mortality in critically ill patients, was calculated for each patient. This system separates the relative contributions to prognosis of chronic health status and previous therapy, the circumstances related to ICU admission, and the presence and degree of physiologic dysfunction.[9]

\section{Oral physical examination}

A dental team composed of residents and professors performed a detailed oral physical examination on the patient's first day of ICU hospitalization, including an examination of the patient's teeth and oral mucosa. A previous training of the team, including review of criteria and protocol, demonstrations and practice examination together with the responsible researcher was carried out for calibration. In the oral examination, we analysed the following characteristics: tooth loss, presence of removable dental prosthesis, visible cavitation of dental caries, dental mobility, oral/gingival bleeding, coated tongue, hairy tongue, depapillated tongue and any other mucosal lesion. After this oral physical examination, the same dental team performed a daily protocol of oral hygienization of teeth and oral mucosa with toothbrushes and gauze soaked in chlorhexidine digluconate $0.12 \%$.

\section{Statistical Analysis}

Data were analysed using Stata/SE 13.0 (StataCorp LP, TX, USA). Comparisons between subgroups of categorical variables with VAP were calculated using Fisher's exact test and Student's t test. Logistic regression was performed to identify independent predictors for VAP, and control for possible confounders, such as age, co-morbidities and reason for ICU admission, which are included in the SAPS3. A $p$ value of $<.05$ was considered significant. 


\section{Results}

The study sample consisted of 663 critically ill patients under mechanical ventilation, most of them with orotracheal tube (633-95.48\%). Most subjects were male (413-62.29\%), while 250 (37.71\%) were female. The mean age of the patients was 57.02 years, with patient age ranging from 18 to 96 years. The most common reason for ICU admission was cardiovascular diseases, corresponding to 152 patients (22.93\%), followed by trauma (112 - 16.89\%), respiratory system diseases $(79-11.92 \%)$, sepsis (77 $11.61 \%)$, gastrointestinal disorders (60 - 9.05\%), malignant neoplasms (21 - 3.17\%), orthopaedic problems (19-2.87\%) and kidney disease (17 - 2.56\%). For the SAPS3, the mean was 67.91 , and the range was from 17 to 114 .

At the oral physical examination, we observed that most patients had some dental loss (568 - 85.67\%), $309(46.61 \%)$ of whom were totally edentulous. Eleven patients $(1.66 \%)$ were intubated without removing removable prosthesis. Visible cavitation of dental caries were found in 155 patients $(23.38 \%)$ and dental mobility in $28(4.22 \%)$. When examining the patient's oral mucosa, 422 patients $(63.65 \%)$ presented coated tongue, $12(1.81 \%)$ had depapillated tongue, and $12(1.81 \%)$ had hairy tongue. Some patients presented other oral mucosal lesions, most of which were oral ulcers (113-17.04\%). In addition, 192 patients $(28.96 \%)$ presented oral/gingival bleeding during the physical examination.

During the period of ICU hospitalization, $118(17.80 \%)$ of the 663 patients developed VAP. Of those 174 patients, 43 (36.44\%) were women and $75(63.56 \%)$ were men, and the mean age of the patients was 53.47 years. For most of them, trauma (32-27.12\%) or cardiovascular diseases ( $26-22.03 \%)$ was the reason for hospitalization, and the mean SAPS3 was 64.97. Patients with PAV had higher mean of SAPS3 comparing to patients who did not develop VAP (64.97 vs $68.55 ; p=0.02)$.

Fisher's exact test revealed that patients with coated tongue or oral/gingival bleeding on the first day of ICU hospitalization developed more VAP than patients without these conditions $(20.14 \%$ vs $13.69 \%$ : $p=0.02 ; 23.44 \%$ vs $15.50 \%$ : $p=0.01$, respectively). The results from the association between all variables with VAP development are summarized in Table 1. The logistic regression showed that these two variables, together with the SAPS3 were included in the analysis to control for possible confounders. Coated tongue and oral bleeding were considered independent risk factors for VAP development [coated tongue: $\mathrm{OR}=1.59$ (95\% Cl: 1.02-2.47), $p=0.02$; oral bleeding: $\mathrm{OR}=1.60$ (95\% Cl: $1.05-2.44) \mathrm{p}=0.03$ ] (Table 2).

\section{Discussion}

Pneumonia is an important cause of morbidity and mortality in the older population. Aspiration is an important pathogenic mechanism for pneumonia in the elderly, and poor oral health and hygiene are increasingly recognized as a major risk factor.[10] VAP remains one of the most common nosocomial infections in the ICU, affecting approximately $10 \%$ to $40 \%$ of the patients on mechanical ventilation, with an overall mortality of approximately $13 \% .[11,12]$ Patients with VAP need longer periods of ventilatory 
assistance and hospital stays, in addition to an increased level of care and the need for additional procedures and treatments. $[8,13]$ The diagnosis of VAP represents approximately US $\$ 40,000$ of additional hospital costs per patient. $[8,13]$ Patients who develop VAP seem to have twice the risk of death compared to similar patients without VAP.[14] The percentage of patients on mechanical ventilation who developed VAP in our study (18.69\%) was similar to the findings in the literature.

The oral cavity is an important source of bacteria that may cause lung infections, and several studies have associated the presence of oral biofilm with the development of VAP. Dental plaque, which is a complex biofilm relatively resistant to chemical control,[15] accumulates rapidly in the oral cavity of critically ill patients.[4] Dental plaque in hospitalized patients with chronic lung diseases may serves as a reservoir of bacteria known to cause nosocomial pneumonia in susceptible individuals.[16] The oral cavity of patients on mechanical ventilation contains high amounts of respiratory pathogens such as methicillin-resistant Staphylococcus aureus, Pseudomonas aeruginosa, and gram-negative bacilli.[17] These same pathogens were identified in the lungs of patients on mechanical ventilation who developed VAP. $[18,19]$ In a prospective study evaluating oral health and VAP development among 162 critically ill patients, Saenson et al. (2016)[20] found a strong association between poor oral health and increased risk for early-onset VAP. Munro et al. (2006)[5] reported that more dental plaque and lower salivary volume are correlated with a high rate of pneumonia. Azarpazhooh and Leake (2006)[21] also found that poor oral health significantly increases the risk of pneumonia, up to 9.6-fold. Nakajima et al. (2020) found that bacterial pneumonia, poor oral hygiene, and severe dry mouth were significantly associated with oral candidiasis.[22] We found a high incidence of dental-related problems among our patients; however, only coated tongue and oral bleeding were considered independent risk factors for the development of VAP. Oral bleeding may be a sign of biofilm-induced gingivitis or be secondary to traumatic ulcers. In addition, the presence of blood clots in the oral cavity in patients with oral bleeding may favour bacterial proliferation and increase the risk of VAP.

The coated tongue forms on the dorsal surface and includes keratin, food residue and bacteria attached to the tongue papillae.[23] The surface of the tongue dorsum is filled with papillae, which increases the area available for bacterial colonization and facilitates the accumulation of desquamated epithelium and food debris.[24] It represents an important reservoir for bacteria, including periodontopathic bacteria.[25] Patients with a coated tongue present a higher number of salivary bacteria than patients without this alteration, and several reports have indicated that tongue cleaning reduced the total number of these microorganisms.[26] In a study involving 71 edentulous elderly adults in nursing homes, those with a coated tongue demonstrated significantly higher salivary bacterial counts than those without it, suggesting that a coated tongue could be a risk factor for aspiration pneumonia.[27] Kageyama et al. (2018)[28] also reported that tongue microbiota is related to the risk of and death via aspiration pneumonia among elderly patients living in nursing homes. Dry mouth has been associated with a coated tongue and VAP.[29, 30]. In our study, we found a high incidence of coated tongue, representing $63.80 \%$ of all patients. It was also considered an independent risk factor for VAP development. These results reinforce the importance of adequate oral hygiene, including teeth and oral mucosa, especially the tongue. We know that in cases of illness, oral hygiene can be neglected. 
Given that the microbiota of the oral cavity plays an important role in the development of VAP, some studies have indicated that the initiation of the topical application of antiseptic agents, such as chlorhexidine, before intubation reduces nosocomial infections. $[18,19]$ The value of chlorhexidine oral care has been studied extensively. A meta-analysis including 12 randomized studies encompassing 2341 patients reported a significant overall risk reduction in VAP in patients with chlorhexidine hygienization. [31] Oral hygiene with chlorhexidine has been proposed as one of the five components of a core set of interventions in the ventilator bundle defined by the Institute for Healthcare Improvement. In our patients, daily oral hygienization with chlorhexidine was performed but only after ICU admission, and most patients were intubated beforehand.

Some limitations of our study should be mentioned. First, the oral physical examination, which was difficult in some cases, mainly due to the tube and their securement devices. Second, the caries diagnosis is much more complex than just a visual physical examination, involving detection of active white-spot lesions and sometimes with the help of interproximal radiographs. So, in our study, only visible cavitation was considered, not taking into account which and how many teeth involved.

Besides, a cross-sectional study has some limitation, once the investigator measures the outcome and the exposures in the study participants at the same time. However, this methodology can be used to calculate the odds radio as a measure of association, and it has been used to evaluate risk-factors for pneumonia, including VAP.[32-34]

According to our results and within the limits of the study, we may conclude that the presence of a coated tongue and oral bleeding in the ICU admission could be considered markers of VAP development in critically ill patients. Proper maintenance of oral hygiene, especially the tongue, before intubation may lead to a decrease in the incidence of VAP in the ICU. This issue becomes even more important now in the current pandemic COVID-19 scenario, where more people are expected to need mechanical ventilation.

\section{Declarations}

\section{Compliance with Ethical Standards}

Conflict of Interest: Author Ademar Takahama Junior declares that he has no conflict of interest. Author Vitoria laros de Sousa declares that she has no conflict of interest. Author Elisa Emi Tanaka declares that she has no conflict of interest. Author Evelise Ono declares that she has no conflict of interest. Author Fernanda Akemi Nakanishi Ito declares that she has no conflict of interest. Author Priscila Paganini Costa declares that she has no conflict of interest. Author Maria Beatriz Bergonse Pedrialli declares that she has no conflict of interest. Author Heliton Gustavo de Lima declares that he has no conflict of interest. Author Marco Aurélio Fornazieri declares that he has no conflict of interest. Author Leticia Sassaki Correia declares that she has no conflict of interest. Author Lucienne Tibery Queiroz Cardoso declares that she has no conflict of interest. Author Claudia Maria Dantas de Maio Carrilho declares that she has no conflict of interest. 
Funding: The work was supported by Universidade Estadual de Londrina, PROPPG, Escritório de Apoio ao Pesquisador

Ethical approval: All procedures performed were in accordance with the ethical standards of the institutional and/or national research committee and with the 1964 Helsinki declaration and its later amendments or comparable ethical standards.

Informed consent: Informed consent was obtained from all individual participants included in the study.

\section{References}

1. X. L, K.M. K, L. T, I. O (2000) Systemic diseases caused by oral infection. Clin Microbiol Rev 13:547558

2. Paju S, Scannapieco FA (2007) <Oral biofilms pulmonary infections Paju Scannapieco 2007.pdf>. 508-512. https://doi.org/10.1111/j.1601-0825.2007.1410a.x

3. linuma T, Arai Y, Abe Y, et al (2015) Denture wearing during sleep doubles the risk of pneumonia in the very elderly. J Dent Res 94:28S-36S. https://doi.org/10.1177/0022034514552493

4. Fourrier F, Duvivier B, Boutigny $\mathrm{H}$, et al (1998) Colonization of dental plaque: A source of nosocomial infections in intensive care unit patients. Crit Care Med 26:301-308. https://doi.org/10.1097/00003246-199802000-00032

5. Grap MJ, Munro CL, Elswick RK, et al (2004) Duration of action of a single, early oral application of chlorhexidine on oral microbial flora in mechanically ventilated patients: A pilot study. Hear Lung J Acute Crit Care 33:83-91. https://doi.org/10.1016/j.hrtlng.2003.12.004

6. Arabi Y, Al-Shirawi N, Memish Z, Anzueto A (2008) Ventilator-associated pneumonia in adults in developing countries: a systematic review. Int J Infect Dis 12:505-512. https://doi.org/10.1016/j.ijid.2008.02.010

7. Centers for Disease Control and Prevention (2019) (Ventilator-associated Pneumonia [ VAP] and non-ventilator-associated Pneumonia [ PNEU ]) Event. Device-associated Modul CDC 1-16

8. Kollef MH, Hamilton CW, Ernst FR (2012) Economic Impact of Ventilator-Associated Pneumonia in a Large Matched Cohort. Infect Control Hosp Epidemiol 33:250-256. https://doi.org/10.1086/664049

9. Moreno RP, Metnitz PGH, Almeida E, et al (2005) SAPS 3 - From evaluation of the patient to evaluation of the intensive care unit. Part 2: Development of a prognostic model for hospital mortality at ICU admission. Intensive Care Med 31:1345-1355. https://doi.org/10.1007/s00134-0052763-5

10. Janssens JP, Krause KH (2004) Pneumonia in the very old. Lancet Infect Dis 4:112-124. https://doi.org/10.1016/S1473-3099(04)00931-4

11. Melsen WG, Rovers MM, Groenwold RHH, et al (2013) Attributable mortality of ventilator-associated pneumonia: A meta-analysis of individual patient data from randomised prevention studies. Lancet Infect Dis. https://doi.org/10.1016/S1473-3099(13)70081-1 
12. Van Vught LAV, Klouwenberg PMCK, Spitoni C, et al (2016) Incidence, risk factors, and attributable mortality of secondary infections in the intensive care unit after admission for sepsis. JAMA - J Am Med Assoc 315:1469-1479. https://doi.org/10.1001/jama.2016.2691

13. Warren DK, Shukla SJ, Olsen MA, et al (2003) Outcome and attributable cost of ventilator-associated pneumonia among intensive care unit patients in a suburban medical center. Crit Care Med 31:13121317. https://doi.org/10.1097/01.CCM.0000063087.93157.06

14. Safdar N, Dezfulian C, Collard HR, Saint S (2005) Clinical and economic consequences of ventilatorassociated pneumonia: A systematic review. Crit Care Med 33:. https://doi.org/10.1097/01.CCM.0000181731.53912.D9

15. Marsh PD (2010) Microbiology of dental plaque biofilms and their role in oral health and caries. Dent. Clin. North Am.

16. Didilescu AC, Skaug N, Marica C, Didilescu C (2005) Respiratory pathogens in dental plaque of hospitalized patients with chronic lung diseases. Clin Oral Investig 9:141-147. https://doi.org/10.1007/s00784-005-0315-6

17. Zuanazzi D, Souto R, Mattos MBA, et al (2010) Prevalence of potential bacterial respiratory pathogens in the oral cavity of hospitalised individuals. Arch Oral Biol 55:21-28. https://doi.org/10.1016/j.archoralbio.2009.10.005

18. Bahrani-Mougeot FK, Paster BJ, Coleman S, et al (2007) Molecular analysis of oral and respiratory bacterial species associated with ventilator-associated pneumonia. J Clin Microbiol 45:1588-1593. https://doi.org/10.1128/JCM.01963-06

19. Heo S, Haase EM, Lesse AJ, et al (2008) Genetic Relationships between Respiratory Pathogens Isolated from Dental Plaque and Bronchoalveolar Lavage Fluid from Patients in the Intensive Care Unit Undergoing Mechanical Ventilation. Clin Infect Dis 47:1562-1570. https://doi.org/10.1086/593193

20. Saensom D, Merchant AT, Wara-aswapati N, et al (2016) Oral health and ventilator-associated pneumonia among critically ill patients: a prospective study. Oral Dis 22:709-714. https://doi.org/10.1111/odi.12535

21. Azarpazhooh A, Leake JL (2006) Systematic Review of the Association Between Respiratory Diseases and Oral Health. J Periodontol 77:1465-1482. https://doi.org/10.1902/jop.2006.060010

22. Nakajima M, Umezaki Y, Takeda S, et al (2020) Association between oral candidiasis and bacterial pneumonia: A retrospective study. Oral Dis 26:234-237. https://doi.org/10.1111/odi.13216

23. Ogami K, Ueda T, Ryu M, et al (2018) Evaluation of Factors Associated with Tongue Coating Status in Elderly with Care Needs. Bull Tokyo Dent Coll 59:163-169. https://doi.org/10.2209/tdcpublication.2017-0041

24. Washio J, Sato T, Koseki T, Takahashi N (2005) Hydrogen sulfide-producing bacteria in tongue biofilm and their relationship with oral malodour. J Med Microbiol 54:889-895. https://doi.org/10.1099/jmm.0.46118-0 
25. Yasui M, Ryu M, Sakurai K, Ishihara K (2012) Colonisation of the oral cavity by periodontopathic bacteria in complete denture wearers. Gerodontology 29:494-502. https://doi.org/10.1111/j.17412358.2011.00506.x

26. Yonezawa $\mathrm{H}$, Takasaki K, Teraoka K, et al (2003) Effects of tongue and oral mucosa cleaning on oral Candida species and production of volatile sulfur compounds in the elderly in a nursing home. $\mathrm{J}$ Med Dent Sci 50:1-8

27. Abe S, Ishihara K, Adachi M, Okuda K (2008) Tongue-coating as risk indicator for aspiration pneumonia in edentate elderly. Arch Gerontol Geriatr 47:267-275. https://doi.org/10.1016/j.archger.2007.08.005

28. Kageyama S, Takeshita T, Furuta M, et al (2018) Relationships of variations in the tongue microbiota and pneumonia mortality in nursing home residents. Journals Gerontol - Ser A Biol Sci Med Sci 73:1097-1102. https://doi.org/10.1093/gerona/glx205

29. Koshimune S, Awano S, Gohara K, et al (2003) Low salivary flow and volatile sulfur compounds in mouth air. Oral Surg Oral Med Oral Pathol Oral Radiol Endod 96:38-41. https://doi.org/10.1016/S1079-2104(03)00162-8

30. Nalcaci R, Baran I (2008) Oral malodor and removable complete dentures in the elderly. Oral Surgery, Oral Med Oral Pathol Oral Radiol Endodontology 105:5-9. https://doi.org/10.1016/j.tripleo.2008.02.016

31. Labeau SO, van de Vyver K, Brusselaers N, et al (2011) Prevention of ventilator-associated pneumonia with oral antiseptics: A systematic review and meta-analysis. Lancet Infect Dis 11:845854. https://doi.org/10.1016/S1473-3099(11)70127-X

32. Naruishi K, Nishikawa Y, Kido J ichi, et al (2018) Relationship of aspiration pneumonia to cognitive impairment and oral condition: a cross-sectional study. Clin Oral Investig 22:2575-2580. https://doi.org/10.1007/s00784-018-2356-7

33. Kusahara DM, da Cruz Enz C, Avelar AFM, et al (2014) Risk factors for ventilator-associated pneumonia in infants and children: A crosssectional cohort study. Am J Crit Care 23:469-476. https://doi.org/10.4037/ajcc2014127

34. Inai Y, Nomura Y, Takarada T, et al (2020) Risk factors for postoperative pneumonia according to examination findings before surgery under general anesthesia. Clin Oral Investig. https://doi.org/10.1007/s00784-020-03230-7

\section{Tables}

Table 1. Oral findings in the 663 patients according to the development of VAP. 


\begin{tabular}{|c|c|c|c|c|}
\hline ral Characteristics & Without VAP & With VAP & p* & TOTAL \\
\hline $\begin{array}{l}\text { oated Tongue } \\
\text { o } \\
\text { es } \\
\end{array}$ & $\begin{array}{l}208(86.31 \%) \\
337(79.86 \%) \\
\end{array}$ & $\begin{array}{l}33(13.69 \%) \\
85(20.14 \%) \\
\end{array}$ & 0.02 & $\begin{array}{l}241(\%) \\
422(\%) \\
\end{array}$ \\
\hline $\begin{array}{l}\text { ral/gingival bleeding } \\
\text { o } \\
\text { es }\end{array}$ & $\begin{array}{l}398(84.50 \%) \\
147(76.56 \%) \\
\end{array}$ & $\begin{array}{l}73(15.50 \%) \\
45(23.44 \%) \\
\end{array}$ & 0.01 & $\begin{array}{l}471(\%) \\
192(\%) \\
\end{array}$ \\
\hline $\begin{array}{l}\text { ooth loss } \\
\text { o } \\
\text { es }\end{array}$ & $\begin{array}{l}76(80 \%) \\
469(82.57 \%)\end{array}$ & $\begin{array}{l}19 \text { (20\%) } \\
99(17.43 \%)\end{array}$ & 0.31 & $\begin{array}{l}95(\%) \\
568(\%) \\
\end{array}$ \\
\hline $\begin{array}{l}\text { aries } \\
\text { o } \\
\text { as } \\
\end{array}$ & $\begin{array}{l}417(82.09 \%) \\
128(82.58 \%) \\
\end{array}$ & $\begin{array}{l}91(19.91 \%) \\
27(17.42 \%) \\
\end{array}$ & 0.49 & $\begin{array}{l}508(\%) \\
155(\%) \\
\end{array}$ \\
\hline $\begin{array}{l}\text { ooth mobility } \\
\text { o } \\
\text { es } \\
\end{array}$ & $\begin{array}{l}525(82.68 \%) \\
20(71.43 \%) \\
\end{array}$ & $\begin{array}{l}110(17.32 \%) \\
8(28.57 \%)\end{array}$ & 0.10 & $\begin{array}{l}635(\%) \\
28(\%) \\
\end{array}$ \\
\hline $\begin{array}{l}\text { tubated using removable prosthesis } \\
\text { o } \\
\text { es }\end{array}$ & $\begin{array}{l}535(82.06 \%) \\
10(90.91 \%) \\
\end{array}$ & $\begin{array}{l}117(17.94 \%) \\
1(9.09 \%)\end{array}$ & 0.39 & $\begin{array}{l}652(\%) \\
11(\%) \\
\end{array}$ \\
\hline $\begin{array}{l}\text { airy tongue } \\
\text { o } \\
\text { as }\end{array}$ & $\begin{array}{l}534(82.03 \%) \\
11(91.67 \%) \\
\end{array}$ & $\begin{array}{l}117(17.97 \%) \\
1(8.33 \%)\end{array}$ & 0.34 & $\begin{array}{l}651(\%) \\
12(\%)\end{array}$ \\
\hline $\begin{array}{l}\text { epapillated tongue } \\
\text { o } \\
\text { es } \\
\end{array}$ & $\begin{array}{l}535(82.18 \%) \\
10(83.33 \%) \\
\end{array}$ & $\begin{array}{l}116(17.82 \%) \\
2(16.67 \%) \\
\end{array}$ & 0.63 & $\begin{array}{l}651(\%) \\
12(\%) \\
\end{array}$ \\
\hline $\begin{array}{l}\text { ral ulcers } \\
\text { o } \\
\text { es }\end{array}$ & $\begin{array}{l}456(82.91 \%) \\
89(78.76 \%)\end{array}$ & $\begin{array}{l}94(17.09 \%) \\
24(21.24 \%) \\
\end{array}$ & 0.17 & $\begin{array}{l}550(\%) \\
113(\%) \\
\end{array}$ \\
\hline
\end{tabular}

Fisher's exact test $(\mathrm{p}<0.05)$

Table 2. Analysis of independent factors for VAP.

\begin{tabular}{l|c|c|c|c|c|}
\hline ral findings/VAP & Odds Ratio & Std. Err. & $\mathrm{z}$ & $\mathrm{P}>|\mathbf{z}|$ & {$[95 \%$ Conf. Interval] } \\
\hline ral bleeding & 1.60 & .344 & 2.21 & 0.02 & {$[1.054,2.444]$} \\
\hline sated tongue & 1.59 & .358 & 2.06 & 0.03 & {$[1.023,2.475]$} \\
\hline tPS3 & .98 & .006 & -2.18 & 0.02 & {$[.9732, .9985]$} \\
\hline
\end{tabular}

Logistic regression $(\mathrm{p}<0.05)$

\section{Supplementary Files}

This is a list of supplementary files associated with this preprint. Click to download.

- tables.docx 